\section{(6) OPEN ACCESS}

\title{
Changes in blood gas transport of altitude native soccer players near sea-level and sea-level native soccer players at altitude (ISA3600)
}

\author{
Nadine Wachsmuth, ${ }^{1}$ Marlen Kley, ${ }_{1}^{1}$ Hilde Spielvogel, ${ }^{2}$ Robert J Aughey, ${ }^{3,4}$ \\ Christopher J Gore, ${ }^{5,6}$ Pitre C Bourdon, ${ }^{7}$ Kristal Hammond, ${ }^{4}$ Charli Sargent, $^{8}$ \\ Gregory D Roach, ${ }^{8}$ Rudy Soria Sanchez, ${ }^{2}$ Jesus C Jimenez Claros, ${ }^{2}$ Walter F Schmidt, ${ }^{1}$ \\ Laura A Garvican-Lewis ${ }^{9,5}$
}

For numbered affiliations see end of article.

\section{Correspondence to Dr Laura A Garvican,} National Institute of Sports Studies, University of Canberra, Bruce, ACT 2601, Australia; laura.garvican@ausport.gov.au

Accepted 3 September 2013

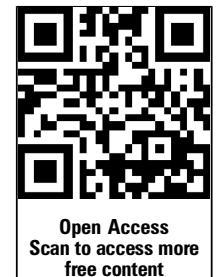

To cite: Wachsmuth $\mathrm{N}$, Kley M, Spielvogel $H$, et al. Br J Sports Med 2013;47: i93-i99.

\section{ABSTRACT}

Objectives The optimal strategy for soccer teams playing at altitude is not known, that is, 'fly-in, fly-out' versus short-term acclimatisation. Here, we document changes in blood gas and vascular volumes of sea-level (Australian, n=20) and altitude (Bolivian, $n=19$ ) native soccer players at $3600 \mathrm{~m}$.

Methods Haemoglobin-oxygen saturation $\left(\mathrm{Hb}^{-} \mathrm{SO}_{2}\right)$, arterial oxygen content $\left(\mathrm{CaO}_{2}\right)$, haemoglobin mass (Hbmass), blood volume (BV) and blood gas concentrations were measured before descent (Bolivians only), together with aerobic fitness (via Yo-YoIR1), near sea-level, after ascent and during 13 days at $3600 \mathrm{~m}$. Results At baseline, haemoglobin concentration $[\mathrm{Hb}]$ and Hbmass were higher in Bolivians (mean \pm SD; 18.2 $\pm 1.0 \mathrm{~g} / \mathrm{dL}, 12.8 \pm 0.8 \mathrm{~g} / \mathrm{kg})$ than Australians $(15.0 \pm 0.9 \mathrm{~g} /$ $\mathrm{dL}, 11.6 \pm 0.7 \mathrm{~g} / \mathrm{kg}$; both $\mathrm{p} \leq 0.001)$. Near sea-level, [Hb] of Bolivians decreased to $16.6 \pm 0.9 \mathrm{~g} / \mathrm{dL}$, but normalised upon return to $3600 \mathrm{~m}$; Hbmass was constant regardless of altitude. In Australians, [ $\mathrm{Hb}$ ] increased after 12 days at $3600 \mathrm{~m}$ to $17.3 \pm 1.0 \mathrm{~g} / \mathrm{dL} ;$ Hbmass increased by 3.0 $\pm 2.7 \%(p \leq 0.01)$. BV decreased in both teams at altitude by $\sim 400 \mathrm{~mL}$. Arterial partial pressure for oxygen $\left(\mathrm{PaO}_{2}\right)$, $\mathrm{Hb}-\mathrm{SO}_{2}$ and $\mathrm{CaO}_{2}$ of both teams decreased within $2 \mathrm{~h}$ of arrival at $3600 \mathrm{~m}(\mathrm{p} \leq 0.001)$ but increased over the following days, with $\mathrm{CaO}_{2}$ overcompensated in Australians (+1.7 $\pm 1.2 \mathrm{~mL} / 100 \mathrm{~mL} ; \mathrm{p} \leq 0.001)$. Yo-YolR1 was lower on the 3rd versus 10 th day at altitude and was significantly related to $\mathrm{CaO}_{2}$.

Conclusions The marked drop in $\mathrm{PaO}_{2}$ and $\mathrm{CaO}_{2}$ observed after ascent does not support the 'fly-in, fly-out' approach for soccer teams to play immediately after arrival at altitude. Although short-term acclimatisation was sufficient for Australians to stabilise their $\mathrm{CaO}_{2}$ (mostly due to loss of plasma volume), 12 days appears insufficient to reach chronic levels of adaption.

\section{INTRODUCTION}

Playing soccer at altitude presents an interesting dilemma for teams. Following reports of discomfort by several South American soccer federations, Federation Internationale de Football Association (FIFA) banned international games at altitudes above $2500 \mathrm{~m}$ in 2007 , but after political intervention, the limit was increased to $3000 \mathrm{~m}$ and shortly thereafter suspended pending more data. FIFA published a consensus statement in 2008, indicating soccer performance is likely compromised at moderate altitude $(2000-3000 \mathrm{~m})$ but that any decrement could be abated within 2 weeks through acclimatisation. ${ }^{1}$

Until now, very little data existed relating to soccer at altitude, especially above $3000 \mathrm{~m}$. The only available published study on $\mathrm{VO}_{2}$ max of professional soccer players from altitude ( $\mathrm{La} \mathrm{Paz}$, $3600 \mathrm{~m}$ ) and near sea-level (Santa Cruz $430 \mathrm{~m}$, both Bolivia) showed a more pronounced decrease in lowlanders when moving from low-land to altitude $(3600 \mathrm{~m})$ than in players adapted to altitude. ${ }^{2}$ The time course of acclimatisation, and hence the optimum preparation strategy, however, is not known. As a consequence of busy match schedules, logistics and monetary constraints, many teams opt for a 'fly-in, fly-out' approach, rather than investing in a longer (1-2 week) acclimatisation phase. Additionally, there is some anecdotal belief that if matches are played within the first few hours of arrival at altitude, physical performance will be less compromised.

Regardless of the acclimatisation strategy employed, reduced oxygen availability at altitude, resulting in low arterial partial pressure for oxygen $\left(\mathrm{PaO}_{2}\right)$ and low arterial oxygen content $\left(\mathrm{CaO}_{2}\right)$, markedly reduces aerobic performance of players from sea-level. ${ }^{2}$ Thus, even acute exposure to altitude triggers a multifaceted response. While $\mathrm{PaO}_{2}$ at altitude mostly depends on the degree of hypoxic ventilation, $\mathrm{CaO}_{2}$ is also determined by the position of the oxygen dissociation curve ${ }^{3}$ and especially by haemoglobin concentration $([\mathrm{Hb}])$ which in turn depends on the loss of body water and thereby changes in blood and plasma volume $(\mathrm{PV})$, and the erythropoietic response. ${ }^{4}$ Acutely, changes in ventilation and diuresis appear to be the most important adaptive mechanisms as the increase in haemoglobin mass (Hbmass) is too slow for immediate needs ${ }^{5}$ and represents a long-term adaptation. Therefore, the primary aim was to document the time-course and magnitude of changes in $\mathrm{CaO}_{2}$ and the corresponding adaptations of Hbmass, and blood volume (BV) in sealevel native soccer players during 2 weeks of exposure at $3600 \mathrm{~m}$.

Altitude residents descending from altitude to sea-level are characterised by a rapidly occurring water retention leading to increased $\mathrm{PV}^{4}{ }^{7}$ When these subjects return to altitude after a short sojourn at sea-level, some physiological functions must 're-adapt' (eg, erythropoietin (EPO) 
secretion), while other functions are able to switch quickly to altitude conditions (eg, ventilation). ${ }^{8}$ The secondary aim of the study was, therefore, to monitor possible blood gas and vascular volume changes in altitude natives following descent to near sea-level and upon return to altitude. In this respect, altitude natives provide a reference for chronic altitude adaptation, and may provide additional insight into acute responses to altered oxygen availability.

\section{METHODS}

\section{Participants}

Thirty-nine youth soccer players provided written informed consent to participate in the study which was approved by two independent Human Ethics Committees. ${ }^{9}$ Players consisted of two teams: 'The Joeys' Australian U17 National team $(n=20)$ and U20 players from 'The Strongest', a professional club based in La Paz $(n=19)$. Australian players were lifetime sea-level residents. Bolivian players were altitude natives, born between $2800 \mathrm{~m}$ and $4100 \mathrm{~m}<$ stet $>$ and residing in La Paz (3200$4100 \mathrm{~m}$ ) at the time of the study. The complete study design and participant characteristics are reported in a companion paper. ${ }^{9}$ Data pertaining to wellness, running performance, activity during matches and sleep architecture are reported in companion papers in this issue. ${ }^{9-13}$

Serum ferritin was assessed 4 weeks prior to the start of the study. Players with values below $<40 \mu \mathrm{g} / \mathrm{L}$ (5 Australians, 4 Bolivians) were immediately supplemented with oral iron daily (305 mg ferrous sulfate). The remaining Australians started supplementation 1 week prior to ascent and continued throughout exposure.

\section{Study design}

Both teams trained for 6 days near sea-level (Santa Cruz, Bolivia, $430 \mathrm{~m}$ ) followed by 13 days of altitude training in $\mathrm{La}$ Paz $(3600 \mathrm{~m})$. Hbmass, BV, [Hb], haemoglobin-oxygen saturation $\left(\mathrm{Hb}-\mathrm{sO}_{2}\right)$, blood gases and the acid-base status of the Bolivians were measured in La Paz, 4-5 days prior to descent and after 5 days near sea-level. Australian players flew to Santa Cruz where baseline haematological measures were established from duplicate measurements taken 2 and 4 days after arrival. Both teams flew to $\mathrm{La} \mathrm{Paz}$ on the sixth day, with blood gas measures performed within $2 \mathrm{~h}$ of arrival. Hbmass, BV and blood gas measures were performed on days 5 (Bolivians) and 7 (Australians) at altitude and at the end of exposure, with additional blood gas measures performed on day 3 (see figure 1 in our companion $\operatorname{paper}^{8}$ ). Hbmass was also measured in 10 Australian players 2 weeks later in Canberra, Australia $(\sim 600 \mathrm{~m})$.

Aerobic fitness was assessed on a grass football pitch on day 2 near sea-level using the Yo-Yo intermittent recovery test level 1 (Yo-YoIR1), ${ }^{14}$ and repeated on days 3 and 10 at altitude (for a complete description see our companion paper ${ }^{11}$ ).

\section{Procedures}

Hbmass was measured using the optimised carbon monoxide rebreathing technique. ${ }^{15}$ A CO bolus of $1.2 \mathrm{~mL} / \mathrm{kg}$ body mass was rebreathed through a glass spirometer for $2 \mathrm{~min}$. The volume of $\mathrm{CO}$ administered at altitude was adjusted according to barometric pressure. Capillary blood was sampled before and 7 min after inhalation and analysed for carboxyhaemoglobin (HbCO) concentration (OSM3, Radiometer, Copenhagen, Denmark). The same analyser was used for all measures in Bolivia. Custom quality controls were analysed to ensure the stability of the analyser, ${ }^{16}$ and to allow comparison in series with the final measurement in Australia, where a second analyser was used. Since the quality controls were stable, no corrections were performed.

Capillary haemoglobin concentration $(\mathrm{c}[\mathrm{Hb}])$ was measured in duplicate using a Hemocue Hb201 System (Cypress, USA) before each rebreathing test after the subjects had been seated for at least $10 \mathrm{~min}$ and used to calculate $\mathrm{BV}$. Blood gases $\left(\mathrm{PaO}_{2}\right.$, $\left.\mathrm{PaCO}_{2}\right), \mathrm{Hb}-\mathrm{sO}_{2}, \mathrm{pH}$, actual bicarbonate $\left(\left[\mathrm{HCO}_{3}^{-}\right]\right)$and base excess (BE) were measured from capillary blood (ABL80Flex, Radiometer, Copenhagen, Denmark).

\section{Statistics}

Data are presented as mean \pm SDs. Paired t-test's including a Bonferroni correction were applied to compare mean within groups and unpaired t-tests were used for a comparison of Australians and Bolivians at corresponding time-points. Linear regression analysis was used to evaluate the dependency of $\mathrm{Hb}-\mathrm{sO}_{2}$ on $\mathrm{PaCO}_{2}$ and Yo-YoIR1 distance at altitude on $\mathrm{CaO}_{2}$.
Figure 1 Haemoglobin oxygen saturation $\left(\mathrm{Hb}-\mathrm{sO}_{2}\right)$ in arterialised blood of Australian (AUS) and Bolivian (BOL) soccer players at near sea level and during the 12 day acclimatisation period at $3600 \mathrm{~m}$ *** indicates the group differences from the data at sea level. +++ indicates the significance of differences between both teams $(+p<0.05,++p<0.01,+++p<0.001)$.

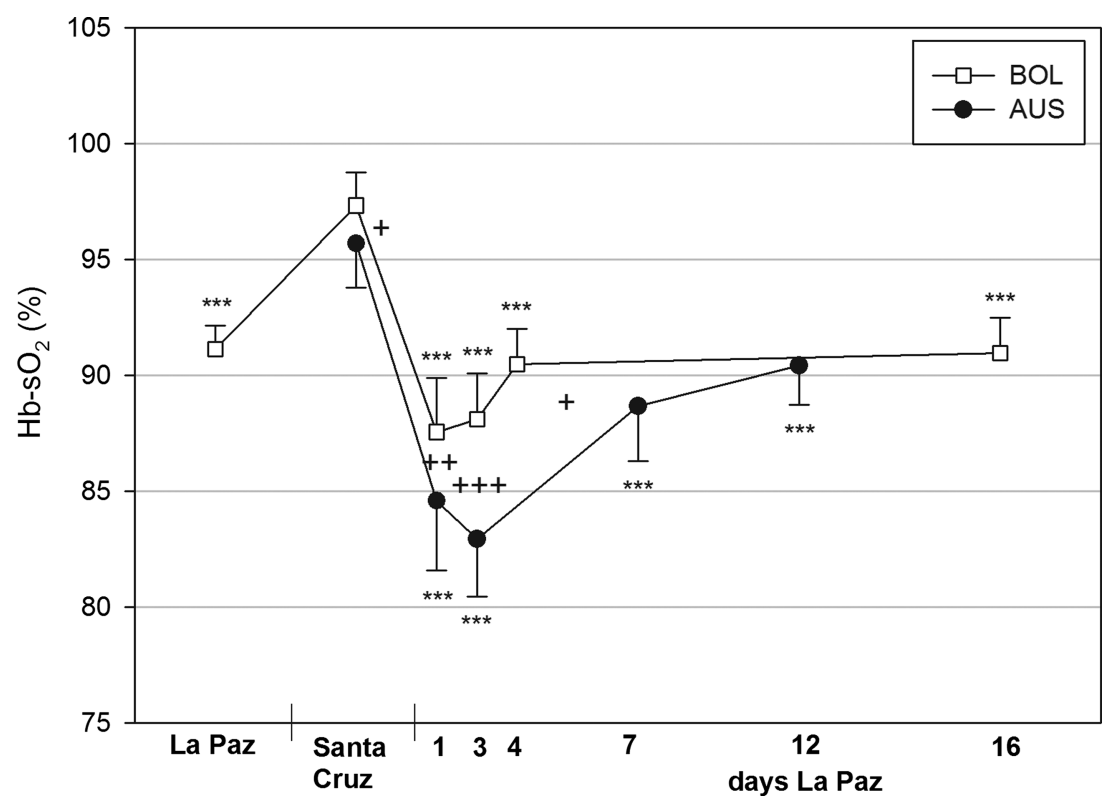


A mixed model with $\mathrm{Hb}-\mathrm{sO}_{2}$, $\mathrm{Hbmass}$ and $\mathrm{BV}$ as covariates was calculated to quantify their effects on $\mathrm{CaO}_{2}$ when Bolivians descended to Santa Cruz and after ascent of both teams to La Paz.

\section{RESULTS}

$\mathrm{PaO}_{2}$ (table 1) and $\mathrm{Hb}-\mathrm{sO}_{2}$ (figure 1 ) increased in Bolivians near sea-level and decreased in both teams within $2 \mathrm{~h}$ of arrival at

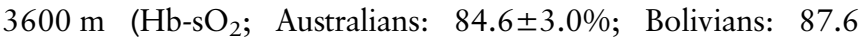
$\pm 2.3 \% ; \mathrm{p} \leq 0.001)$. Both parameters remained low for 3 days, with a greater decrease in Australians, before increasing in the following days $\left(\mathrm{Hb}-\mathrm{sO}_{2}\right.$; Australians: 90.4 $1.7 \%$, Bolivians: $91.0 \pm 1.5 \%, \mathrm{p} \leq 0.001)$.

$\mathrm{PaCO}_{2}$ (table 1) considerably increased in Bolivians near sealevel. Upon ascent, $\mathrm{PaCO}_{2}$ of both teams was unchanged within $2 \mathrm{~h}$ of arrival, but was lower at day 3 and continued to drop throughout exposure.

$\mathrm{pH}$ decreased in Bolivians after arrival near sea-level, did not change in either team after 3 days at altitude and slightly increased thereafter (table 1 ). $\left[\mathrm{HCO}_{3}^{-}\right]$and $\mathrm{BE}$ did not change in Australians $2 \mathrm{~h}$ after arrival at altitude and significantly decreased over the following days (table 1). No substantial group differences existed for $\mathrm{PaCO}_{2}$ and $\mathrm{pH}\left[\mathrm{HCO}_{3}^{-}\right]$and $\mathrm{BE}$ decreased slightly faster in Bolivians.

Linear regression analysis showed significant negative relationships between $\mathrm{Hb}-\mathrm{sO}_{2}$ and $\mathrm{PaCO}_{2}$ in both groups (figure 2). At identical $\mathrm{PaCO}_{2}, \mathrm{Hb}-\mathrm{sO}_{2}$ was higher in the Bolivians.

Baseline [Hb] and Hbmass were $15.0 \pm 0.9 \mathrm{~g} / \mathrm{dL}$ and 797 $\pm 75 \mathrm{~g}$, respectively, in Australians and $18.2 \pm 1.0 \mathrm{~g} / \mathrm{dL}$ and 833 $\pm 104 \mathrm{~g}$ in Bolivians. After descending, near sea-level [Hb] (figure 3A) decreased in Bolivians to $16.7 \pm 0.9 \mathrm{~g} / \mathrm{dL}(\mathrm{p}<0.001)$ and after 5 days back at altitude almost reached predescent levels $(17.8 \pm 0.6 \mathrm{~g} / \mathrm{dL}, \mathrm{p}<0.001)$. In Australians, near sea-level [Hb] was clearly lower vs Bolivians and increased markedly during altitude exposure $(17.3 \pm 1.0 \mathrm{~g} / \mathrm{dL}, \mathrm{p}<0.001)$. Absolute Hbmass (figure $3 \mathrm{~B}$ ) remained unchanged in Bolivians, but significantly increased in Australians $(+25.8 \mathrm{~g}, \mathrm{p}<0.001)$. Relative Hbmass (figure 3C) was clearly different between both groups at baseline (Australians: $11.5 \pm 0.7 \mathrm{~g} / \mathrm{kg}$, Bolivians $13.3 \pm 0.8 \mathrm{~g} / \mathrm{kg}$, $\mathrm{p}<0.001)$. Near sea-level relative Hbmass significantly decreased in Bolivians $(12.8 \pm 0.8 \mathrm{~g} / \mathrm{kg}, \mathrm{p}<0.01)$ but returned to baseline at altitude. In Australians, relative Hbmass significantly increased at altitude $(12.3 \pm 0.9 \mathrm{~g} / \mathrm{kg}, \mathrm{p}<0.001)$ without achieving the values of Bolivians, and remained elevated in 10 players measured 2 weeks later in Australia.
Before descending, BV (figure 3D) was significantly lower in Bolivians $(5306 \pm 637 \mathrm{~mL}$, Australians: $6040 \pm 503 \mathrm{~mL}, \mathrm{p}<0.01)$ and increased near sea-level by $518 \pm 306 \mathrm{~mL}$ to the same level as Australians. At altitude, BV decreased in both groups by $>400 \mathrm{~mL}$ (Bolivians at day $55395 \pm 683 \mathrm{~mL}$, Australians at day 12: $5608 \pm 621 \mathrm{~mL}, \mathrm{p}<0.001)$.

In Bolivians, $\mathrm{CaO}_{2}$ (figure 4) only slightly dropped after descent $(22.5 \pm 1.3 \mathrm{~mL} / \mathrm{dL})$ and remained significantly higher vs Australians $(20.0 \pm 1.5 \mathrm{~mL} / \mathrm{dL})$. Upon ascent, $\mathrm{CaO}_{2}$ significantly decreased in both teams $2 \mathrm{~h}$ after arrival (Australians: 17.7 $\pm 1.4 \mathrm{~mL} / \mathrm{dL}$, Bolivians: $20.3 \pm 1.2 \mathrm{~mL} / \mathrm{dL}, \mathrm{p}<0.001)$ and considerably increased the following days achieving baseline values in Bolivians (at day 5: $22.3 \pm 1.0 \mathrm{~mL} / \mathrm{dL}$ ) and showing a significant overcompensation in Australians (at day 12: $21.8 \pm 1.4 \mathrm{~mL} / \mathrm{dL}$, $\mathrm{p}<0.001$ )

The results of an analysis of covariance demonstrate that in both teams, the increase in $\mathrm{CaO}_{2}$ during acclimatisation (Australians) or reacclimatisation (Bolivians) to high altitude is mostly due to the decrease in BV followed by an increase in $\mathrm{Hb}-\mathrm{sO}_{2}$, and for Australians, only partially to the increase in Hbmass (table 2).

Results of Yo-YoIR1 are presented in a companion paper. ${ }^{11}$ Briefly, total distance covered in the Yo-YoIR1 decreased in both teams at altitude compared to near sea-level, but to a greater extent in Australians. After 10 days, distance was restored to near sea-level values in the Bolivians but not Australians. Linear regression analysis showed a significant positive relationship between $\mathrm{CaO}_{2}$ and Yo-YoIR1 distance (figure 5).

\section{DISCUSSION}

This is the first study, to our knowledge, to examine the time course of BV and ventilatory responses to altitude in soccer players. The main finding was that ventilatory responses were delayed for a few hours upon ascent, with $\mathrm{CaO}_{2}$ consequently compromised in the short-term. Over time, $\mathrm{CaO}_{2}$ was compensated by increased hypoxic ventilation, a decrease in BV and, in Australians only, an increase in Hbmass.

\section{BV, [Hb] and Hbmass}

At baseline, the Bolivians were characterised by a higher Hbmass and $[\mathrm{Hb}]$ but smaller BV than Australians; the first of which demonstrates long-term adaptation to life-long living at altitude. $^{7} 17 \quad 18$ Following descent, absolute values of Hbmass

Table 1 Arterial oxygen partial pressure $\left(\mathrm{PaO}_{2}\right)$ and acid-base status in Australian (AUS) and Bolivian (BOL) football players at near sea-level and during 12 days at $3600 \mathrm{~m}$

\begin{tabular}{|c|c|c|c|c|c|c|c|}
\hline & & La Paz Day 5 & Santa Cruz & La Paz Day 1 & La Paz Day 3 & La Paz Day 5/7 & La Paz Day 12/16 \\
\hline $\mathrm{PaO}_{2}(\mathrm{~mm} \mathrm{Hg})$ & $\begin{array}{l}\text { AUS } \\
\text { BOL }\end{array}$ & $54.3 \pm 2.4^{* * *, x x x}$ & $\begin{array}{l}71.3 \pm 8.5 \\
75.7 \pm 6.8\end{array}$ & $\begin{array}{l}43.9 \pm 2.6^{* * *,+++} \\
48.2 \pm 3.4^{* * *}\end{array}$ & $\begin{array}{l}43.5 \pm 2.1^{* * *,+++} \\
47.9 \pm 2.5^{* * *, x x x}\end{array}$ & $\begin{array}{l}51.1 \pm 3.7^{* * *, x x x} \\
51.9 \pm 2.2^{* * *, x x x}\end{array}$ & $\begin{array}{l}56.1 \pm 2.2^{* * *,}, \mathrm{xx},+++ \\
60.0 \pm 2.6^{* * *,} \mathrm{xxx}\end{array}$ \\
\hline $\mathrm{PaCO}_{2}(\mathrm{~mm} \mathrm{Hg})$ & $\begin{array}{l}\text { AUS } \\
\text { BOL }\end{array}$ & $30.5 \pm 1.6^{* * *}$ & $\begin{array}{l}39.7 \pm 2.4 \\
39.4 \pm 3.0\end{array}$ & $\begin{array}{l}39.1 \pm 2.3 \\
38.7 \pm 3.3\end{array}$ & $\begin{array}{l}35.8 \pm 2.3^{* * *} \\
34.9 \pm 2.9^{* * *}\end{array}$ & $\begin{array}{l}32.4 \pm 2.3 * * * \\
33.3 \pm 2.3 * * *\end{array}$ & $\begin{array}{l}30.7 \pm 1.3^{* * *} \\
31.9 \pm 2.0^{* * *}\end{array}$ \\
\hline $\mathrm{pH}$ & $\begin{array}{l}\text { AUS } \\
\text { BOL }\end{array}$ & $7.44 \pm 0.02 * * *$ & $\begin{array}{l}7.40 \pm 0.03 \\
7.41 \pm 0.02\end{array}$ & $\begin{array}{l}7.40 \pm 0.02 \\
7.40 \pm 0.03\end{array}$ & $\begin{array}{l}7.38 \pm 0.01 * \\
7.40 \pm 0.02\end{array}$ & $\begin{array}{l}7.42 \pm 0.03^{* * *} \\
7.43 \pm 0.02 * * *\end{array}$ & $\begin{array}{l}7.43 \pm 0.02 * * * \\
7.42 \pm 0.02^{*}\end{array}$ \\
\hline Actual bicarbonate (mmol/L) & $\begin{array}{l}\text { AUS } \\
\text { BOL }\end{array}$ & $20.7 \pm 1.3^{* * *}$ & $\begin{array}{l}24.8 \pm 1.1 \\
24.1 \pm 1.4\end{array}$ & $\begin{array}{l}24.1 \pm 1.3 \\
23.0 \pm 1.9 * *\end{array}$ & $\begin{array}{l}20.4 \pm 2.0^{* * *} \\
20.9 \pm 1.3^{* * *}\end{array}$ & $\begin{array}{l}20.6 \pm 1.3^{* * *}+ \\
21.6 \pm 1.1^{* * *}\end{array}$ & $\begin{array}{l}20.1 \pm 0.7^{* * *} \\
20.5 \pm 1.0^{* * *}\end{array}$ \\
\hline base excess (mmol/L) & $\begin{array}{l}\text { AUS } \\
\text { BOL }\end{array}$ & $-2.8 \pm 1.4^{* * *}$ & $\begin{array}{l}0.7 \pm 1.2 \\
0.1 \pm 1.1\end{array}$ & $\begin{array}{c}0.1 \pm 1.6 \\
-1.1 \pm 1.8^{* *}\end{array}$ & $\begin{array}{l}-3.6 \pm 1.5^{* * *} \\
-3.2 \pm 1.2^{* * *}\end{array}$ & $\begin{array}{l}-3.3 \pm 1.7^{* * *,+} \\
-2.1 \pm 0.8^{* * *}\end{array}$ & $\begin{array}{l}-3.4 \pm 0.9 * * * \\
-3.3 \pm 1.1 * * *\end{array}$ \\
\hline
\end{tabular}

Significant differences from the near sea-level values are indicated as ${ }^{*} p<0.05,{ }^{* *} p<0.01,{ }^{* * *} p<0.001$

Significant differences from the value determined $2 \mathrm{~h}$ after arrival at altitude (only for $\mathrm{PaO}_{2}$ ) are indicated by ${ }^{\mathrm{xxx}} \mathrm{p}<0.001$.

Differences between the Australian and Bolivian football players are presented as ${ }^{+} p<0.05,{ }^{+++} p<0.001$.

$\mathrm{PaCO}_{2}$, arterial partial pressure for $\mathrm{CO}_{2}$. 
Figure 2 Relationship between haemoglobin oxygen saturation $\left(\mathrm{Hb}-\mathrm{sO}_{2}\right)$ and arterial partial pressure of carbon dioxide $\left(\mathrm{PaCO}_{2}\right)$ which Data are obtained from day 1 to day 12 at altitude (BOL at day 16). During the first days at altitude $\mathrm{Hb}-\mathrm{O}_{2}$-saturation is higher in $\mathrm{BOL}$ at identical $\mathrm{PaCO}_{2}$. AUS, Australian players, BOL, Bolivian players. reflects the degree of hyperventilation.

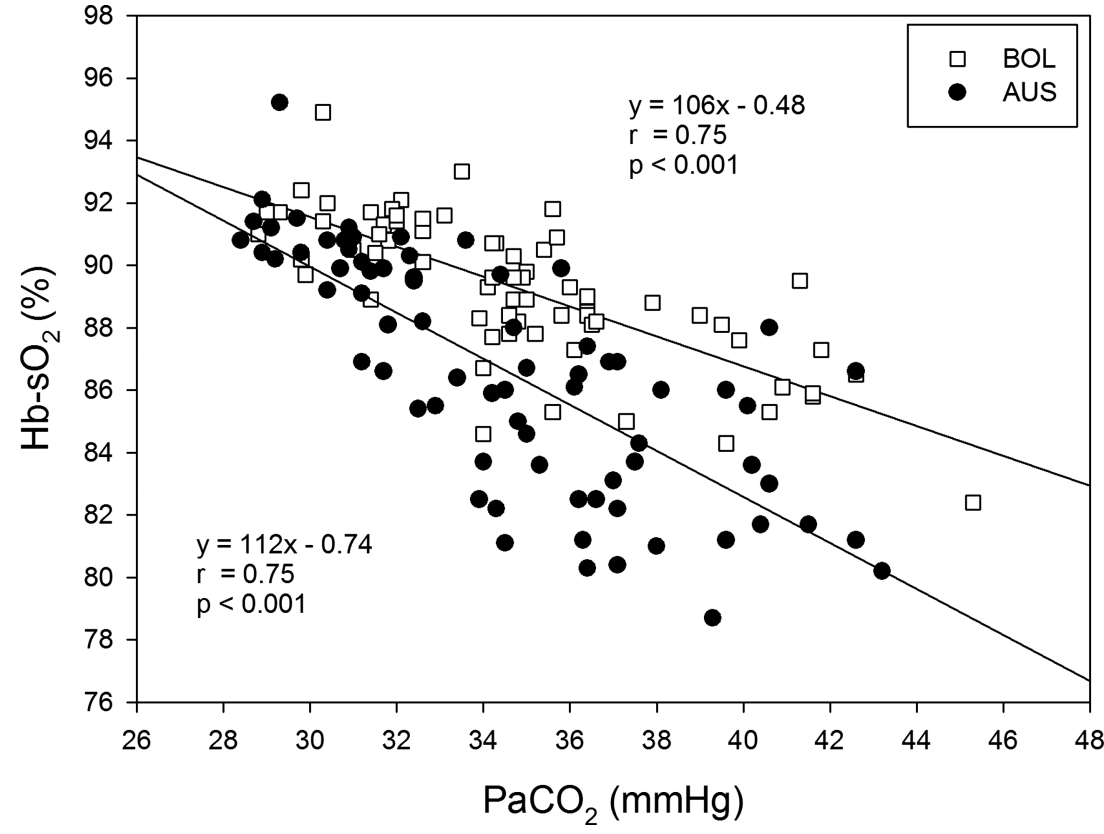

were held constant in the Bolivians, with no evidence of neocytolysis observed after 5 days. Neocytolysis describes the selective destruction of neocytes deemed to be in excess following a change in environment, ${ }^{19}{ }^{20}$ for example, following altitude
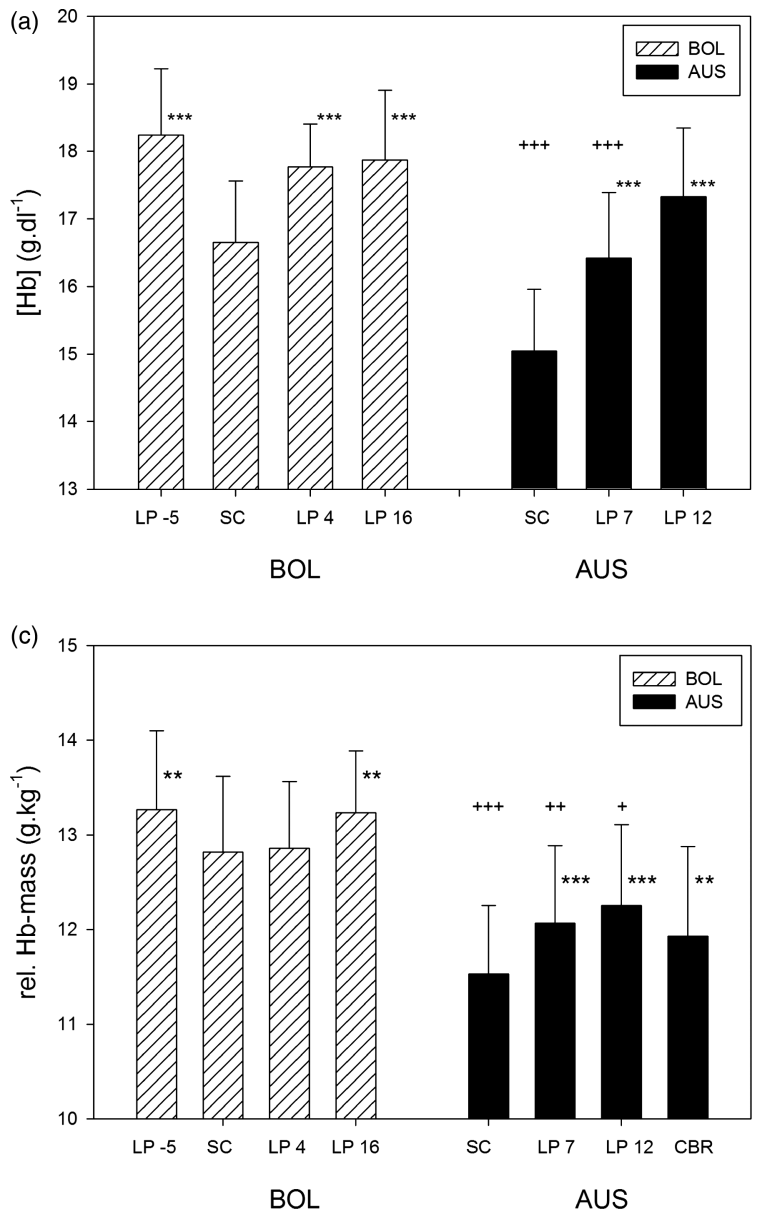

exposure. ${ }^{21}$ Our observations are similar to those in Kenyan altiwas not observed until a number of weeks at sea-level, ${ }^{22}$ indicating that in altitude natives living at $3600 \mathrm{~m}$ or lower, any
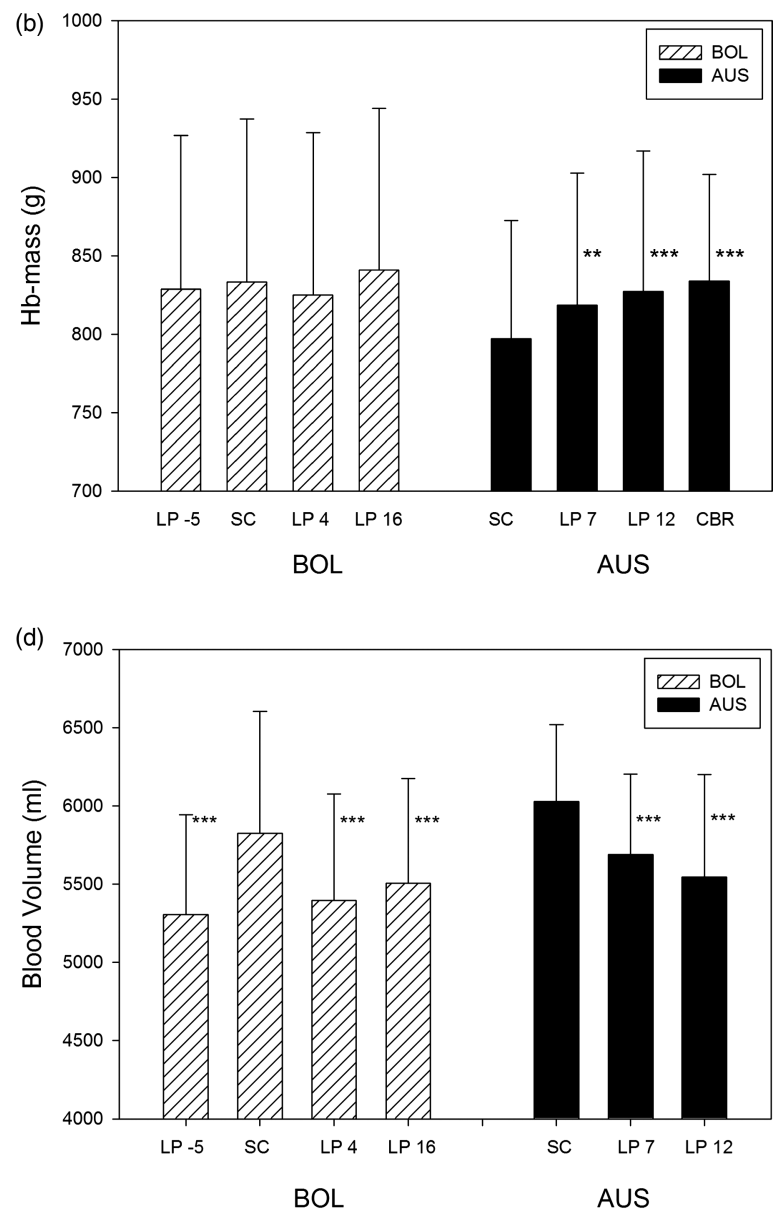
tude natives training at sea-level, where a decrease in Hbmass

Figure 3 (A) Haemoglobin concentration, (B) absolute haemoglobin mass (Hbmass), (C) relative haemoglobin mass (rel. Hbmass), (D) blood volume of Australian (AUS) and Bolivian (BOL) players at near sea-level (430) and after ascent to altitude (3600 m). 
Figure 4 Oxygen content in arterialised blood $\left(\mathrm{CaO}_{2}\right)$. For statistical information see figure 1 .

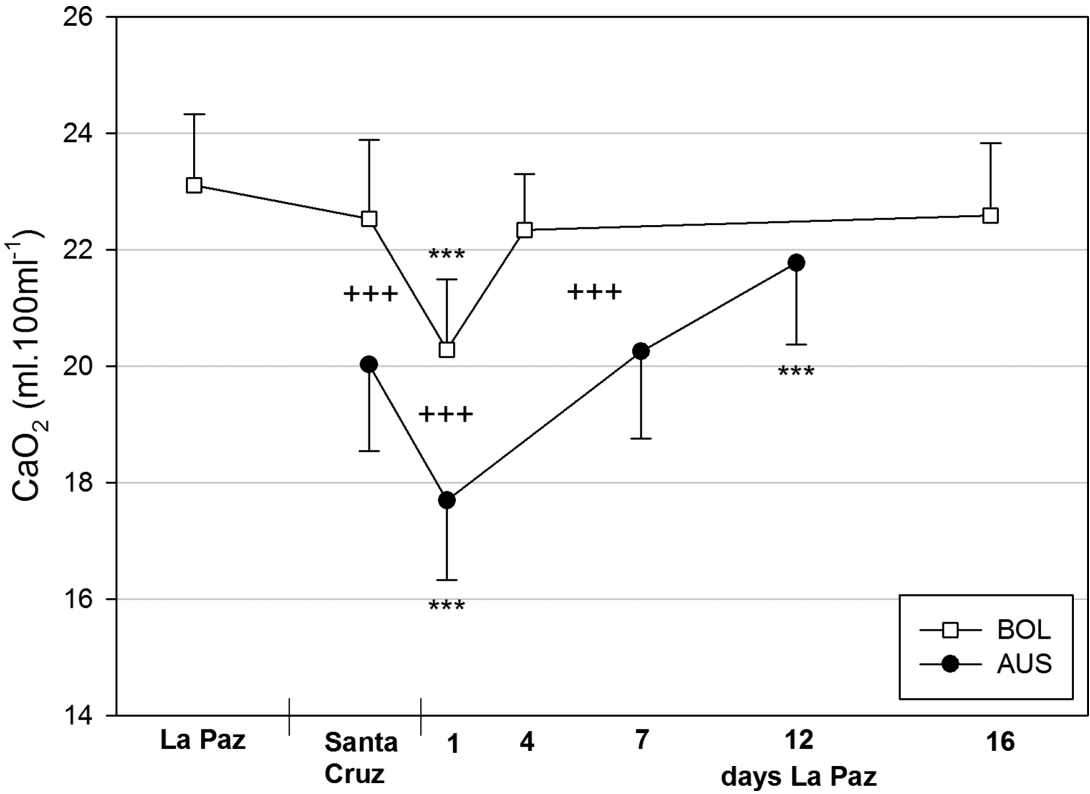

decrease in Hbmass is a result of slowly altered red cell turnover as opposed to rapid neocytolysis.

The changes to $\mathrm{BV}$ and [Hb] observed in the Bolivians near sea-level were quickly restored to baseline levels after 5 days at $3600 \mathrm{~m}$. Thus, it appears that even though altitude natives undergo several changes when they descend to low altitude, these adaptations are relatively labile and allow them to acclimatise quickly upon return to altitude, through changes in altitude diuresis. Although the acute time course of changes in BV during the first day of altitude could not be determined, we may assume them to be negligible. Previously, we have demonstrated that PV and extracellular water remained unchanged in the first day after ascent to $3600 \mathrm{~m}$ but considerably decreased the following days, due to hormonally provoked diuresis. ${ }^{23}$ Similarly, Loeppky et $a l^{24}$ report an unchanged PV within $10 \mathrm{~h}$ exposure to reduced barometric pressure of $432 \mathrm{~mm} \mathrm{Hg}$ (corresponding to an altitude of $\sim 4300 \mathrm{~m}$ ). The magnitude of decrease in BV of Australians and Bolivians determined over the subsequent days is consistent with data from others ${ }^{7}$ and can be explained mostly by the action of the diuresis-regulating hormones aldosterone, atrial natriuretic peptide and antidiuretic hormone. ${ }^{25}$ However, the influence of changes in temperature ${ }^{26}$ associated with changing altitude and exercise $\operatorname{load}^{27}$ on PV should also be considered. Since both teams did not considerably change their training habits from the prephase of the study (Santa Cruz) to the time period in La Paz, an influence of physical activity on PV is unlikely. On the other hand, since the day-temperature in La Paz is lower than in Santa Cruz, a thermal influence cannot be completely discounted as is demonstrated by seasonal variation in PV of up to $5 \% .^{28}$ However, since both teams spent the majority of time in Santa Cruz in air-conditioned rooms, we also expect such thermal influence to be minimal.

Conversely, Hbmass of Bolivians was stable at altitude, suggesting that the erythropoietic cascade was not accelerated despite the 6-day sojourn near sea-level, (although without [EPO] and reticulocyte data this assertion cannot be confirmed). Our observations appear to be in contrast to the 'finely controlled erythropoietin regulation' consistently observed in Chilean soldiers during long-term intermittent hypoxic exposure showing increased [EPO] when returning to altitude. ${ }^{7}$ Unfortunately, [EPO] data are unavailable at present, therefore we are unable to draw conclusions on possible differences in epidemiological adaptations over generations ${ }^{17}$ as opposed to during a single lifetime.

An increase in Hbmass was evident in the Australians after 7 days with a further increase measured on day 12. Mean data previously suggests an increase of $1 \%$ per $100 \mathrm{~h}$ of exposure at $3000 \mathrm{~m},{ }^{5} 29$ predicting a $3 \%$ change after 12 days-exactly the value observed. The expanded Hbmass was maintained 2 weeks after exposure in the Australian players who were measured, that is neocytolysis was not observed after their return to sea-level.

\section{Blood gases and acid-base status}

Immediately upon ascent, the challenge of oxygen availability is evident from the changes in blood gases. $\mathrm{PaO}_{2}$ and consequently $\mathrm{Hb}-\mathrm{sO}_{2}$ were dramatically decreased in both teams, with the drop more evident in Australians who lacked any altitude

Table 2 Influence of haemoglobin oxygen saturation $\left(\mathrm{Hb}-\mathrm{sO}_{2}\right)$, haemoglobin mass ( $\left.\mathrm{Hbmass}\right)$ and blood volume on arterial oxygen content $\left(\mathrm{CaO}_{2}\right)$

\begin{tabular}{|c|c|c|c|c|c|}
\hline & $\mathrm{p}$ Value & Estimate & $\mathrm{Cl}(95 \%)$ & AUS day $12,(\%)$ & BOL day $16,(\%)$ \\
\hline $\mathrm{Hb}-\mathrm{sO}_{2}(\%)$ & $<0.001$ & 0.229 & 0.222 to 0.236 & 33 & 34 \\
\hline Hbmass (g) & $<0.001$ & 0.0271 & 0.0264 to 0.0278 & 20 & 8 \\
\hline Blood volume (mL) & $<0.001$ & -0.00395 & -0.00405 to -0.00384 & 42 & 55 \\
\hline
\end{tabular}

Demonstrated are the results of an analysis of covariance (mixed model) and the calculated percentage contribution of $\mathrm{Hb}_{-} \mathrm{SO}_{2}, \mathrm{Hbmass}$ and blood volume on the compensation of CaO $\mathrm{O}_{2}$ after ascent to altitude (difference from day 1 ). 
Figure 5 Relationship between total intermittent recovery test level 1 (Yo-YolR1) performed at altitude (see our accompanying paper ${ }^{11}$ ) and $\mathrm{CaO}_{2}$. Yo-YoIR1 data are obtained from day 3 and day 10 at altitude. Hbmass data are obtained from preascent values and after 12 days of acclimatisation. AUS, Australian players; BOL, Bolivian players. distance covered in the Yo-Yo

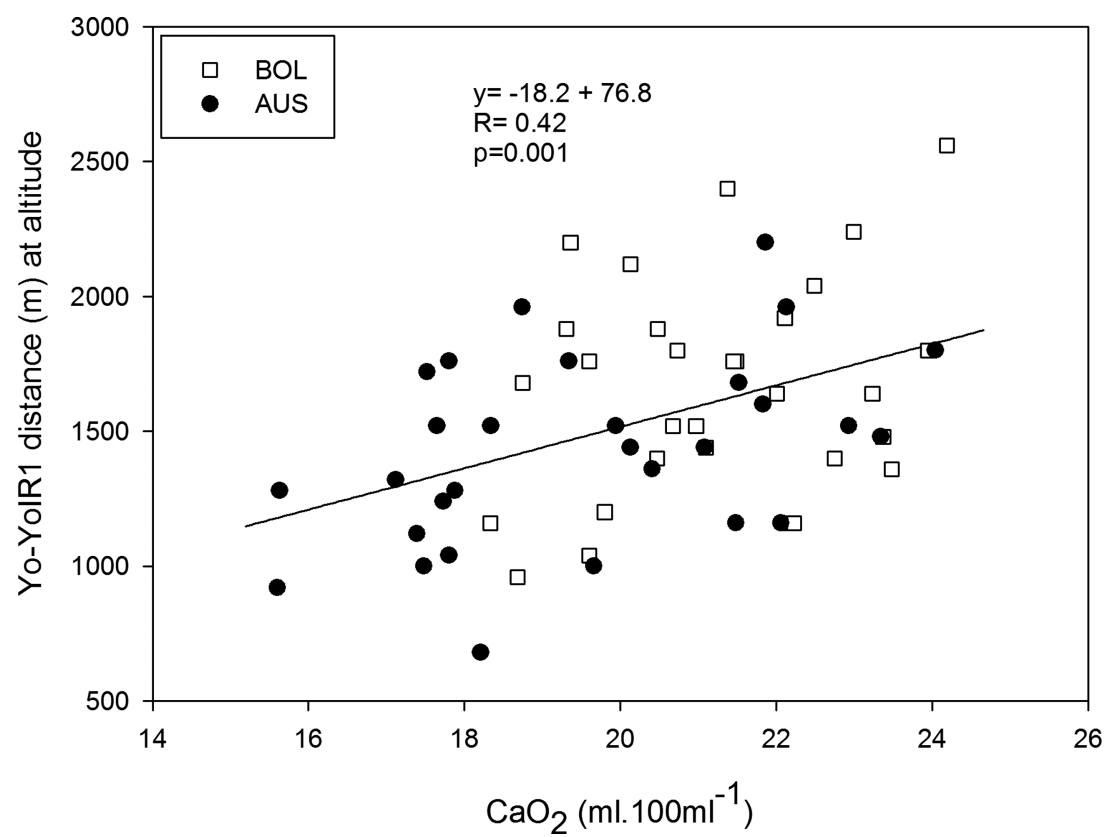

acclimatisation, while Bolivians almost reached altitude baseline values within 5 days of reacclimatisation. $\mathrm{PaCO}_{2}$ was used inversely as a surrogate for ventilatory drive ${ }^{30}$; decreasing markedly in the first few days at altitude as ventilation increased. However, in the first few hours following arrival, the ventilatory drive of both teams remained low, with $\mathrm{PaCO}_{2}$ unchanged after $2 \mathrm{~h}$ at altitude. $\mathrm{PaCO}_{2}$ did not reach a plateau until the second week at altitude, consistent with previous reports that ventilation stabilises after 6 days at $4300 \mathrm{~m}^{31}$

An important long-term adaptation to the altitude environment was evident in the Bolivians in the form of more effective pulmonary diffusion reflected by the higher $\mathrm{PaO}_{2}$ and $\mathrm{Hb}-\mathrm{sO}_{2}$ at similar $\mathrm{PaCO}_{2}$ (figure 2). This finding concurs with previous data showing exceptionally high lung diffusion capacities in high-altitude natives. ${ }^{32}$ The absence of any $\mathrm{pH}$ changes immediately after ascent to altitude was due to the delayed hyperventilation, ${ }^{33}$ whereas the moderate increase in $\mathrm{pH}$ in the following days can be attributed to hyperventilation and not complete renal compensation, which is reflected by the lowered $\left[\mathrm{HCO}_{3}^{-}\right]$ and $\mathrm{BE}$.

\section{Arterial $\mathrm{O}_{2}$-content $\left(\mathrm{CaO}_{2}\right)$}

$\mathrm{CaO}_{2}$ in the Bolivians did not change after 5 days near sea-level, despite a $7 \%$ increase in $\mathrm{Hb}-\mathrm{sO}_{2}$. This hyperventilation effect was counterbalanced by $\sim 10 \%$ increase in BV, resulting in an equivalent drop in [Hb]. After ascent, the immediate fall in $\mathrm{Hb}-\mathrm{sO}_{2}$ decreased $\mathrm{CaO}_{2}$ by $\sim 12 \%$ and $10 \%$ in Australians and Bolivians, respectively; but was completely compensated within 1 week; the most effective mechanism being the lowered PV, followed by ventilatory adaptations (table 2). The increased Hbmass accounts for only $20 \%$ of the $\mathrm{CaO}_{2}$ increase after 12 days and can be considered to be of minor importance for the Australians. However, if a longer acclimatisation period was adopted, and evoked similar Hbmass values to the Bolivians, the contribution of Hbmass to the $\mathrm{CaO}_{2}$ compensation would exceed $50 \%$.

At moderate altitude, the decrease in $\mathrm{CaO}_{2}$ completely explains the reduction in aerobic power, whereas at high altitude $(5300 \mathrm{~m})$, the low $\mathrm{CaO}_{2}$ accounts for approximately two thirds of this loss, ${ }^{34}$ emphasising the importance of $\mathrm{CaO}_{2}$ for endurance performance. Indeed, this notion is supported by the relationship between $\mathrm{CaO}_{2}$ and Yo-YoIR1 distance at altitude as well as the less pronounced decrease in Yo-YoIR1 distance 3 days after arrival at $3600 \mathrm{~m}$ in the Bolivians compared to the Australians (when $\mathrm{CaO}_{2}$ was almost fully compensated), and which subsequently increased to near sea-level values restored by day $10 .{ }^{11}$ Thus, short-term reacclimatisation was likely sufficient to restore aerobic power of the Bolivians in their normal environment, whereas for sea-level natives, it is apparent that an optimal acclimatisation requires more time.

Anecdotal reports have led to a common belief that a 'fly-in, fly-out' approach, with games played within hours of arrival, minimises performance impairment. The almost unchanged acid-base status within $2 \mathrm{~h}$ of arrival indicates a preserved buffer capacity, and may partially support this notion. However, this belief is contradicted by the low $\mathrm{PaO}_{2}$ and $\mathrm{CaO}_{2}$ at the analysis of the activity profile of the players during matches indicates an altitude-induced reduction in match running which is not attenuated by playing immediately upon arrival. ${ }^{10}$

\section{Limitations}

A major limitation of the study is that only physiological data obtained under resting conditions are available. Inferences regarding changes in blood gases and saturation during exercise can only be made based on data currently available in the literature. ${ }^{4}$ Further, it is possible that some responses were compromised in the case of the Australians as a result of mild illness.

\section{CONCLUSION}

Soccer matches at altitude are presently unavoidable. Our data indicate that $\mathrm{CaO}_{2}$ is a major limiting factor for sea-level natives at altitude. The ventilatory response appears to be delayed for several hours after arrival, thereby maintaining a stable acidbase status and buffer capacity, but is unlikely to compensate for the dramatic decrease in $\mathrm{PaO}_{2}$ and $\mathrm{CaO}_{2}$ immediately after ascent. $\mathrm{CaO}_{2}$ is fortunately compensated following a period of acclimatisation. While adaptive differences between native sealevel and altitude residents were still evident after 12 days of acclimatisation, aerobic power was partially recovered, same time point. In addition, global positioning system (GPS) 
indicating 2 weeks of altitude acclimatisation may be a reasonable compromise for sea-level teams required to play at altitude. However, the logistics and time constraints associated with this strategy remain a challenge.

\section{What are the new findings?}

- Arterial oxygen content $\left(\mathrm{CaO}_{2}\right)$ is a major limiting factor for sea-level natives at altitude.

- The ventilatory response appears to be delayed for several hours after arrival, thereby maintaining a stable acid-base status and buffer capacity, but is unlikely to compensate for the dramatic decrease in arterial partial pressure for oxygen and $\mathrm{CaO}_{2}$ immediately after ascent.

- Adaptive differences between native sea-level and altitude residents were still evident after 12 days of acclimatisation, but endurance performance was substantially recovered.

\section{How might the findings impact clinical practice in the} near future:

- Changes in arterial oxygen availability $\left(\mathrm{CaO}_{2}\right)$ following ascent do not appear to support a 'fly-in, fly-out' approach for playing at altitude, although other physiological data should also be considered.

- Two weeks of altitude acclimatisation may be a reasonable compromise for teams required to play at altitude.

\author{
Author affiliations \\ ${ }^{1}$ Department of Sports Medicine/Sports Physiology, University of Bayreuth, Bayreuth, \\ Germany \\ ${ }^{2}$ Facultad de Medicina, Instituto Boliviano de Biología de Altura, Universidad Mayor \\ de San Andrés, La Paz, Bolivia \\ ${ }^{3}$ Institute of Sport, Exercise and Active Living, Victoria University, Melbourne, \\ Australia \\ ${ }^{4}$ Western Bulldogs Football Club, Melbourne, Australia \\ ${ }^{5}$ Department of Physiology, Australian Institute of Sport, Canberra, Australia \\ ${ }^{6}$ Exercise Physiology Laboratory, Flinders University, Adelaide, Australia \\ ${ }^{7}$ ASPIRE Academy for Sports Excellence, Doha, Qatar \\ ${ }^{8}$ Appleton Institute for Behavioural Science, Central Queensland University, Adelaide, \\ Australia \\ ${ }^{9}$ National Institute of Sports Studies, University of Canberra, Canberra, Australia
}

Acknowledgements The authors would like to thank the players and staff of both teams as well as Radiometer, Germany for their technical assistance.

Collaborators Martin Buchheit; Ben M Simpson.

Contributors NW, MK and WFS were involved in acquisition of data, analysis and interpretation of data, drafting the article and approval of the final version. HS was involved in conception and design, critically revising the article for important intellectual content and approved the final version. RJA and CJG were involved in conception and design, analysis and interpretation of data, critically revising article for important intellectual content and approval of the final version. PCB was involved in conception and design, acquisition of data, analysis and interpretation of data, critically revising article for important intellectual content and approval of the final version. $\mathrm{KH}, \mathrm{GDR}$ and JCJC were involved in acquisition of data, critically revising article for important intellectual content and approval of the final version. CS was involved in acquisition of data, critically revising article for important intellectual content. RS was involved in conception and design, acquisition of data, critically revising article for important intellectual content and approval of the final version. LAG-L was involved in conception and design, acquisition, analysis and interpretation of data, drafting the article and approval of the final version.

Competing interests None.
Ethics approval Australian Institute of Sort Human Ethics Committee.

Provenance and peer review Not commissioned; externally peer reviewed.

Open Access This is an Open Access article distributed in accordance with the Creative Commons Attribution Non Commercial (CC BY-NC 3.0) license, which permits others to distribute, remix, adapt, build upon this work non-commercially, and license their derivative works on different terms, provided the original work is properly cited and the use is non-commercial. See: http://creativecommons.org/ licenses/by-nc/3.0/

\section{REFERENCES}

1 Bartsch P, Saltin B. General introduction to altitude adaptation and mountain sickness. Scand J Med Sci Sports 2008;18(Suppl 1):1-10.

2 Brutsaert TD, Spielvogel $H$, Soria $R$, et al. Performance of altitude acclimatized and non-acclimatized professional football (soccer) players at 3,600 M. JEPonline 2000;3:28-37.

3 Winslow RM. The role of hemoglobin oxygen affinity in oxygen transport at high altitude. Respir Physiol Neurobiol 2007;158:121-7.

4 Prommer N, Heinicke K, Viola T, et al. Long-term intermittent hypoxia increases 02-transport capacity but not V02max. High Alt Med Biol 2007;8:225-35.

5 Garvican L, Martin D, Quod M, et al. Time course of the hemoglobin mass response to natural altitude training in elite endurance cyclists. Scand J Med Sci Sports 2012;22:95-103.

6 Wachsmuth NB, Volzke C, Prommer N, et al. The effects of classic altitude training on hemoglobin mass in swimmers. Eur J Appl Physiol 2012;113: $1199-211$.

7 Heinicke K, Prommer N, Cajigal J, et al. Long-term exposure to intermittent hypoxia results in increased hemoglobin mass, reduced plasma volume, and elevated erythropoietin plasma levels in man. Eur J Appl Physiol 2003;88:535-43.

8 Schmidt W, Heinicke K, Rojas J, et al. Blood volume and hemoglobin mass in endurance athletes from moderate altitude. Med Sci Sports Exerc 2002;34:1934-40.

9 Gore CJ, Aughey RJ, Bourdon PC, et al. Methods of the international study on soccer at altitude $3600 \mathrm{~m}$ (ISA3600). Br J Sports Med 2013;47:i80-5.

10 Aughey RJ, Hammond $\mathrm{H}$, Varley $\mathrm{MC}$, et al. Soccer activity profile of altitude versus sea-level natives during acclimatisation to $3600 \mathrm{~m}$ (ISA3600). Br J Sports Med 2013:47:i107-113.

11 Buchheit M, Simpson BM, Garvican-Lewis LA, et al. Wellness, fatigue and physical performance acclimatisation to a 2-week soccer camp at $3600 \mathrm{~m}$ (ISA3600). Br J Sports Med 2013;47:1100-106

12 Sargent $\mathrm{C}$, Schmidt WF, Aughey RJ, et al. The impact of altitude on the sleep of young elite soccer players (ISA3600). Br J Sports Med 2013;47:i86-92.

13 Buchheit M, Simpson BM, Schmidt WF, et al. Predicting sickness during a 2-week soccer camp at $3600 \mathrm{~m}$ (ISA3600). Br J Sports Med 2013;47:i124-7.

14 Bangsbo J, laia FM, Krustrup P. The Yo-Yo intermittent recovery test: a useful tool for evaluation of physical performance in intermittent sports. Sports Med 2008;38:37-51.

15 Schmidt W, Prommer N. The optimised CO-rebreathing method: a new tool to determine total haemoglobin mass routinely. Eur J Appl Physiol 2005;95: 486-95.

16 Gough CE, Sharpe K, Ashenden MJ, et al. Quality control technique to reduce the variability of longitudinal measurement of hemoglobin mass. Scand J Med Sci Sports 2011:21:e365-71.

17 Beall CM. Two routes to functional adaptation: Tibetan and Andean high-altitude natives. Proc Natl Acad Sci USA 2007;104(Suppl 1):8655-60.

18 Beall CM, Brittenham GM, Strohl KP, et al. Hemoglobin concentration of high-altitude Tibetans and Bolivian Aymara. Am J Phys Anthropol 1998; 106:385-400.

19 Alfrey CP, Udden MM, Leach-Huntoon C, et al. Control of red blood cell mass in spaceflight. J Appl Physiol 1996;81:98-104.

20 Rice L, Ruiz W, Driscoll T, et al. Neocytolysis on descent from altitude: a newly recognized mechanism for the control of red cell mass. Ann Intern Med 2001;134:652-6.

21 Pottgiesser T, Garvican LA, Martin DT, et al. Short-term hematological effects upon completion of a four-week simulated altitude camp. Int I Sports Physiol Perform 2012:7:79-83.

22 Prommer N, Thoma S, Quecke L, et al. Total hemoglobin mass and blood volume of elite Kenyan unners. Med Sci Sports Exerc 2010:42:791-7.

23 Schmidt W. Effects of intermittent exposure to high altitude on blood volume and erythropoietic activity. High Alt Med Biol 2002;3:167-76.

24 Loeppky JA, Roach RC, Maes $D$, et al. Role of hypobaria in fluid balance response to hypoxia. High Alt Med Biol 2005;6:60-71.

25 Goldfarb-Rumyantzev AS, Alper SL. Short-term responses of the kidney to high altitude in mountain climbers. Nephrol Dial Transplant 2013. epub ahead of print Mar 22: doi gft051 [pii] 10.1093/ndt/gft051 
26 Sawka MN, Convertino VA, Eichner ER, et al. Blood volume: importance and adaptations to exercise training, environmental stresses, and trauma/sickness. Med Sci Sports Exerc 2000;32:332-48.

27 Convertino VA. Blood volume response to physical activity and inactivity. Am J Med Sci 2007:334:72-9.

28 Doupe J, Ferguson MH, Hildes JA. Seasonal fluctuations in blood volume. Can J Biochem Physiol 1957;35:203-13.

29 Clark SA, Quod MJ, Clark MA, et al. Time course of haemoglobin mass during 21 days live high: train low simulated altitude. Eur J App/ Physio/ 2009;106:399-406.

30 West JB. Respiratory and circulatory control at high altitudes. J Exp Biol 1982;100:147-57.
31 Muza SR, Rock PB, Fulco CS, et al. Women at altitude: ventilatory acclimatization at 4,300 m. J App/ Physiol 2001;91:1791-9.

32 Calbet JA, Lundby $\mathrm{C}$. Air to muscle $\mathrm{O} 2$ delivery during exercise at altitude. High Alt Med Biol 2009;10:123-34.

33 Hultgren $\mathrm{H}$. High altitude medicine. Stanford, California, Hultgren Publications 1997:19-20.

34 Calbet JA, Boushel R, Radegran G, et al. Why is V02 max after altitude acclimatization still reduced despite normalization of arterial $\mathrm{O}_{2}$ content? Am J Physiol Regul Integr Comp Physiol 2003;284: R304-16. 